\title{
Global Estimates of Dietary Intake of Docosahexaenoic Acid and Arachidonic Acid in Developing and Developed Countries
}

\author{
Stewart Forsyth ${ }^{a}$ Sheila Gautier ${ }^{b}$ Norman Salem Jr. ${ }^{a}$ \\ a University of Dundee, Dundee, UK; ${ }^{b}$ DSM Nutritional Products, Columbia, Md., USA
}

\author{
Key Words \\ Arachidonic acid · Docosahexaenoic acid - Global dietary \\ intake $\cdot$ Infants $\cdot$ Adults
}

\begin{abstract}
Background/Aim: For international recommendations on docosahexaenoic acid (DHA) and arachidonic acid (ARA) dietary intake to be valid, there needs to be a greater understanding of dietary patterns across both the developed and developing world. The aim of this investigation was to provide a global overview of dietary intake of DHA and ARA. Methods: Food balance sheets from the Food and Agriculture Organisation Statistics Division and fatty acid composition data from Australian food composition tables in Nutrient Tables 2010 were utilised to generate median per capita intake estimates for DHA and ARA in 175 countries worldwide. Results: Estimated dietary intake per capita for DHA and ARA in 47 developed and 128 developing countries demonstrated that $48 \%$ of the 175 countries have an ARA intake of $<150 \mathrm{mg} /$ day and $64 \%$ have a dietary DHA intake of $<200 \mathrm{mg} /$ day. There was a direct relationship between dietary ARA and DHA intake and the per capita gross national income of the country. Regional analysis showed the lowest ARA and DHA dietary intake in Sub-Saharan Africa and Central and Southern Asian populations. Conclusions: This study demonstrates there are many populations worldwide that have ARA and DHA intake that do not reflect current inter-
\end{abstract}

national recommendations, and the public health consequences of this global inadequacy need to be urgently considered.

(c) 2016 The Author(s)

Published by S. Karger AG, Basel

\section{Introduction}

Long chain polyunsaturated fatty acids (LCPUFAs) attract considerable interest from scientists, clinicians and policymakers because of their roles in key metabolic processes that influence population health and well-being [1, 2]. The n-3 LCPUFAs influence cellular structure and function $[3,4]$, and docosahexaenoic acid (DHA) is especially important in the brain and retina, where it rapidly accumulates during the early years of life [5]. DHA is also the precursor of potent lipid mediators that play crucial roles in the prevention or treatment of common chronic diseases that may lead to significant morbidity and mortality.

The n-6 LCPUFAs, particularly arachidonic acid (ARA), are widely distributed throughout human cells and tissues. In addition to the central nervous system where ARA plays an essential structural and functional role, ARA is also a metabolic requirement for all cells as a precursor for eicosanoids which modulate a variety of biological processes, particularly those relating to cerebral, cardiovascular and immune functions [4]. 
However, despite their biological importance in health and development at all stages of the human life cycle, recommendations on specific dietary requirements for DHA and ARA are inconsistent, and at times controversial [6]. The current relevant scientific evidence is predominantly from surveys and scientific studies that have focused on the needs of populations located within developed countries, and as a consequence, there is a significant lack of information on dietary intake in populations from lowincome countries. For global recommendations to be effective, the evidence needs to be inclusive and in particular, the needs of the most vulnerable populations have to be addressed.

There are 2 key components that may influence DHA and ARA status. First, there is the contribution of endogenous synthesis from the essential precursor 18-carbon n-3 and n-6 fatty acids, linoleic acid and alpha-linolenic acid, respectively; second, there is the contribution from preformed DHA and ARA sources in the diet.

Endogenous synthesis is directed through a metabolic pathway where the n-3 and n-6 fatty acids compete for a shared desaturation and elongation enzyme system. As a consequence, the balance in the intake of the essential 18-carbon n-3 and n- 6 precursors can influence the levels of DHA and ARA derived from endogenous synthesis [7]. Moreover, it is now recognised that this metabolic pathway is relatively inefficient in converting n-3 and n-6 precursor fatty acids to DHA and ARA respectively, especially in early life when organ development is at its peak [8-13].

The competition between $n-3$ and n- 6 fatty acids is particularly evident at the rate-limiting $\Delta 5$ - and $\Delta 6$ desaturase steps in the metabolic pathway. It is now recognised that, in addition to substrate competition, the efficiency of the $\Delta 5$ - and $\Delta 6$-desaturase steps is also dependent on the genotype of fatty acid desaturase (FADS) 1 and FADS2, both located on chromosome 11, and which encode $\Delta 5$ - and $\Delta 6$-desaturase enzymes, respectively [7]. Several studies have reported associations between single nucleotide polymorphisms (SNPs) in the FADS genes and LCPUFA status, with carriers of the minor alleles of FADS SNPs being associated with lower red blood cell content of LCPUFAs, most notably of ARA $[14,15]$. Moreover, there is emerging data to confirm that there is global variation in the prevalence of the minor alleles of FADS SNPs and this may contribute to population differences in LCPUFA status and subsequent health outcomes [16]. Although these metabolic and genetic factors may influence the LCPUFA status, and recommendations on dietary intake of n-3 and n-6 LCPUFAs need to be sensitive to their effects, the adequacy of the dietary intake will play the dominant role in determining the LCPUFA status of a population [17].

In 2003, the World Health Organisation stated that in the general population diets should provide an adequate intake of PUFAs to prevent adverse outcomes, especially cardiovascular disease, and it was recommended that this should be in the range $6-10 \%$ of daily energy intake and that there should be an optimal balance between $n-6$ and n-3 PUFAs of 5-8 and 1-2\% of daily energy intake per day, respectively [18]. In 2010, the European Food Safety Authority (EFSA), basing their recommendation in adults on cardiovascular considerations, indicated an adequate adult intake of $250 \mathrm{mg} /$ day for eicosapentaenoic acid (EPA) plus DHA [19]. For pregnant and lactating women, they recommended an additional 100-200 mg DHA. EFSA also recommended an adequate intake of $100 \mathrm{mg}$ DHA for older infants ( $>6$ months of age) and young children below the age of 24 months. For children aged $2-18$ years EFSA indicated that dietary advice for children should be consistent with that of the adult population (i.e., 1-2 fatty fish meals per week or $250 \mathrm{mg}$ of EPA plus DHA per day). The International Society for the Study of Fatty Acids and Lipids had previously recommended that at least $500 \mathrm{mg}$ /day of EPA and DHA in the general adult population was required to maintain cardiovascular health [20]. In 2010, the Food and Agricultural Organisation (FAO) of the United Nations provided specific recommendations on n-3 LCPUFA for pregnant and lactating women indicating a requirement of $300 \mathrm{mg} /$ day of DHA and EPA of which at least $200 \mathrm{mg} /$ day should be DHA [21]. In relation to young children, FAO recommended that for $0-6$ months, the requirement is $0.1-0.18 \%$ energy (equivalent to a mean of $102 \mathrm{mg} /$ day) of DHA; for 6-24 months, DHA 10-12 mg/kg body weight; 2-4 years, DHA and EPA $100-150 \mathrm{mg}$ /day; increasing to DHA and EPA of 200-250 mg at age 6-10 years.

Regarding ARA, the dietary recommendations are few, but food surveys report the intake of ARA to be between 50 and $300 \mathrm{mg} /$ day for adults consuming westernstyle diets [22]. Recommendations for infants and children are also few with a recommendation of $140 \mathrm{mg}$ ARA/ day for infants during the first 6 months of life [23], and for young children, the Belgian Health Council [24] recommended that the ARA content of the diet should be $0.10-0.25 \%$ energy (102-258 mg/day), and DHA 0.10 $0.40 \%$ energy (102-413 mg/day). However, a subsequent food survey indicated that children aged between 2.5 and 3 years in Belgium had a limited DHA intake of $45 \mathrm{mg} /$ day and for ARA, $17 \mathrm{mg} /$ day [25].

It is evident that for international recommendations on DHA and ARA dietary intake to be valid and repre- 
Table 1. Weight percentage of food losses and waste at the retail (R) and consumption (C) level by type of food and geographical region (FAO, 2011)

\begin{tabular}{|c|c|c|c|c|c|c|c|c|c|c|c|c|}
\hline \multirow[t]{3}{*}{ Food } & \multicolumn{12}{|c|}{ Region } \\
\hline & \multicolumn{2}{|c|}{ Europe } & \multicolumn{2}{|c|}{$\begin{array}{l}\text { North America } \\
\text { and Oceania }\end{array}$} & \multicolumn{2}{|c|}{$\begin{array}{l}\text { Sub-Saharan } \\
\text { Africa }\end{array}$} & \multicolumn{2}{|c|}{$\begin{array}{l}\text { North Africa, } \\
\text { West and } \\
\text { Central Asia }\end{array}$} & \multicolumn{2}{|c|}{$\begin{array}{l}\text { South and } \\
\text { South-East } \\
\text { Asia }\end{array}$} & \multicolumn{2}{|c|}{ Latin America } \\
\hline & $\mathrm{R}$ & $\mathrm{C}$ & $\mathrm{R}$ & $\mathrm{C}$ & $\mathrm{R}$ & $\mathrm{C}$ & $\mathrm{R}$ & $\mathrm{C}$ & $\mathrm{R}$ & $\mathrm{C}$ & $\mathrm{R}$ & $\mathrm{C}$ \\
\hline Fish/seafood & 9 & 11 & 9 & 33 & 15 & 2 & 10 & 4 & 15 & 2 & 10 & 4 \\
\hline Meat & 4 & 11 & 4 & 11 & 7 & 2 & 5 & 8 & 7 & 4 & 5 & 6 \\
\hline Milk and eggs & 0.5 & 7 & 0.5 & 15 & 10 & 0.1 & 8 & 2 & 10 & 1 & 8 & 4 \\
\hline
\end{tabular}

sentative of global populations, there needs to be a greater understanding of dietary patterns across both the developed and developing world.

The aim of this investigation is to provide a global overview of dietary intake of DHA and ARA, which will clarify the international variation in the LCPUFA diet, identify those countries that are most vulnerable to deficiency, and provide a baseline for the needs of the most vulnerable groups within populations.

\section{Methods}

\section{Estimating Global Dietary Intake of DHA and ARA}

Consumption Data

The FAO of the United Nations has prepared food balance sheets (FBS) on regular intervals since the 1940s [26]. The objective of a FBS is to present a comprehensive picture of the pattern of a country's food supply during a specified reference period [27]. The FAO compiles yearly FBS data from 179 countries and includes more than 100 foods and agricultural products from country-level data on the production, use (e.g., seed, livestock feed, food processing, non-food uses and losses) and trade of food commodities. The FBS show national availability for each food item, that is, for each primary commodity and a number of processed commodities that is potentially available for human consumption. It also shows the sources of supply for these commodities and their utilization. The total quantity of foodstuffs produced in a country added to the total quantity imported and adjusted to any change in stocks that may have occurred since the beginning of the reference period gives the supply available during that period. On the utilization side, a distinction is made between the quantities exported, fed to livestock, used for seed, put to manufacture for food use and other uses, losses during storage and transportation, and food supplies available for human consumption. The per capita supply of each food item available for human consumption is then calculated by dividing the respective quantity by the related data on the population actually consuming the food items. Data on per capita food supplies are expressed in terms of quantity and by applying appropriate food composition factors for all primary and processed products, caloric value and protein and fat content can be determined.
The extent of intake of foods rich in DHA and ARA from a global perspective was estimated using per capita consumption data in FAOSTAT from 2009 through 2011 [27]. In order to account for variations from year to year in consumption and food availability, 3-year average consumption estimates were calculated. Data were available for Europe, North America, Australia and New Zealand, and Japan and China in the developed world, and for 4 regions (Africa, Asia, Latin America and Caribbean) and 128 countries in the developing world.

\section{Wastage}

It is important to note that the quantities of food available for human consumption, as estimated in the FAO FBS, relate simply to the quantities of food reaching the consumer and is not a direct measure of what is actually consumed. The amount of food actually consumed may therefore be lower than the quantity shown in the FBS depending on the degree of losses of edible food and nutrients at the stage of retail or within the household, for example, during storage, preparation, plate-waste, discarded or fed to domestic animals. Wastage occurring earlier in the food chain during production, distribution and processing is taken into consideration as an element in the FBS, but wastage occurring at retail and household levels is not included.

The Swedish Institute for Food and Biotechnology, on behalf of FAO has reconstructed mass flows of food for human consumption, from production to consumption, using available data, in order to specifically quantify food losses and wastage and they have estimated levels of wastage at consumer level for all the developed and developing countries included in this analysis [28]. This wastage data was therefore utilised to further refine the estimated levels of per capita consumption (table 1).

\section{Fatty Acid Composition Data}

Databases relating to the fatty acid composition of foods were evaluated, and it was noted that most databases represented the more affluent countries, and in these countries, the measurement of individual fatty acids was not included in the majority of the databases. The levels of ARA and DHA in foods are available in the US Department of Agriculture (USDA) Nutrient Database (NDB) for Standard Reference Release 27 [29]; however, a major limitation of using the USDA NDB data is that there was no reporting of differentiated omega- 6 ARA levels in milk, poultry, eggs, fish, and other meats. In contrast, this data was available in the Australia Nutrient Tables (NUTTAB) database [30]. 
Table 2. Average levels of DHA and ARA in select food categories from the Australia NUTTAB database (FSANZ, 2011)

\begin{tabular}{lll}
\hline Food category, g/100 g food & Australia (2010) \\
\cline { 2 - 3 } & ARA & DHA \\
\hline Eggs & 0.18 & 0.02 \\
Fish, seafood & 0.05 & 0.31 \\
Bovine, meat & 0.05 & 0.005 \\
Mutton (goat), meat & 0.08 & 0.01 \\
Poultry, meat & 0.07 & 0.01 \\
Pig, meat & 0.06 & 0.01 \\
Meat, other & 0.06 & 0.01 \\
Offals, edible & 0.13 & 0.07 \\
Milk & 0.002 & 0.00 \\
\hline
\end{tabular}

Table 3. Median per capita daily consumption (g/day) of egg, fish, meat, and milk commodities based on 2009-2011 FAO FBS in developed and developing countries

\begin{tabular}{|c|c|c|c|c|c|c|c|c|c|c|}
\hline Countries & Eggs & $\begin{array}{l}\text { Fish, } \\
\text { seafood }\end{array}$ & $\begin{array}{l}\text { Bovine, } \\
\text { meat }\end{array}$ & $\begin{array}{l}\text { Mutton } \\
\text { (goat), } \\
\text { meat }\end{array}$ & $\begin{array}{l}\text { Poultry, } \\
\text { meat }\end{array}$ & $\begin{array}{l}\text { Pig, } \\
\text { meat }\end{array}$ & $\begin{array}{l}\text { Meat, } \\
\text { other }\end{array}$ & $\begin{array}{l}\text { Total } \\
\text { meat }\end{array}$ & $\begin{array}{l}\text { Offal, } \\
\text { edible }\end{array}$ & $\begin{array}{l}\text { Milk } \\
\text { (excl } \\
\text { butter) }\end{array}$ \\
\hline Australia and New Zealand & 19.0 & 42.7 & 82.5 & 37.4 & 86.5 & 50.8 & 5.0 & 262.2 & 15.7 & 435 \\
\hline USA and Canada & 30.3 & 36.9 & 80.3 & 1.7 & 102.0 & 62.7 & 1.1 & 247.8 & 2.1 & 577 \\
\hline China & 45.3 & 75.5 & 11.9 & 7.1 & 31.7 & 87.9 & 2.8 & 141.4 & 8.4 & 83 \\
\hline
\end{tabular}

There are food composition databases relating to some developing countries; however, in the databases that contain fatty acid measurements, the number of foods that is included is limited and not sufficiently complete to provide a reasonable estimate of the total ARA and DHA intake from known dietary sources. It was concluded that the data from the Australian food composition database is the most detailed and inclusive and would allow global comparative analyses across developed and developing countries (table 2).

DHA is primarily found in animal tissue lipids, with the highest source being fish. ARA is also found in animal tissue lipids with the highest levels from beef, poultry, eggs and milk. The calculation of the average fatty acid levels in the selected food categories was limited to the raw forms of each food reported in NUTTAB 2010 [30]. There is no data on the cooking practices and this is bound to vary between countries. Since the FAO FBS data is based on availability of foods at the commodity level, fatty acid levels in the raw, unprocessed food was considered to be most applicable. Egg consumption levels were based on whole eggs.

\section{Gross National Income Data}

The relationship of the developmental status of the country to dietary intake was assessed using the measurement of per capita gross national income (GNI) [31], with the countries grouped as high income (GNI per capita greater than USD 12,276), upper-middle income (USD 3,976-USD 12,276), lower-middle income (USD 1,006USD 3,975) and low income (less than USD 1,005 per capita).

\section{Geographical Factors}

As access to coastal areas may allow greater consumption of seafood and thus influence the DHA and ARA dietary intake of these countries, the effect of being bordered by coastline or being landlocked was investigated using coastline data from the Central Intelligence Agency [32].

\section{Demographic Factors}

Relevant demographic factors including population [33] and birth rate data [34] were considered in the analysis.

Data were analysed using IBM SPSS Statistics 22, and as key data did not have a normal distribution the relevant data are presented as the median and the minimum and maximum range.

\section{Results}

Dietary intake of DHA and ARA has been estimated for 175 countries worldwide, 47 classified as developed and 128 as developing. A summary of the per capita consumption estimates for food commodities that are sources of DHA and ARA and the calculated intake of DHA and ARA and percentage daily energy intake are provided in tables 3-5. 
Table 4. Median per capita daily intake of ARA (mg/day) and percent of daily total energy intake (\% energy) from food sources

\begin{tabular}{|c|c|c|c|c|c|c|c|c|c|c|c|c|}
\hline \multirow[t]{2}{*}{ Countries } & \multirow{2}{*}{$\begin{array}{l}\text { Energy } \\
\text { intake, } \\
\text { kcal/day }\end{array}$} & \multicolumn{10}{|c|}{ Per capita daily intake of ARA from food sources, $\mathrm{mg} /$ day } & \multirow{2}{*}{$\begin{array}{l}\text { ARA } \\
\text { as } \% \\
\text { energy }\end{array}$} \\
\hline & & eggs & $\begin{array}{l}\text { fish, } \\
\text { seafood }\end{array}$ & $\begin{array}{l}\text { bovine, } \\
\text { meat }\end{array}$ & $\begin{array}{l}\text { mutton } \\
\text { (goat), } \\
\text { meat }\end{array}$ & $\begin{array}{l}\text { poultry, } \\
\text { meat }\end{array}$ & $\begin{array}{l}\text { pig, } \\
\text { meat }\end{array}$ & $\begin{array}{l}\text { meat, } \\
\text { other }\end{array}$ & $\begin{array}{l}\text { offals, } \\
\text { edible }\end{array}$ & milk & total & \\
\hline European Union & 3,420 & 53.1 & 25.0 & 20.2 & 2.5 & 34.6 & 51.0 & 2.4 & 9.2 & 12.0 & 210 & 0.055 \\
\hline Australia and New Zealand & 3,170 & 34.2 & 21.4 & 41.3 & 29.9 & 60.6 & 30.5 & 3.0 & 20.4 & 8.7 & 250 & 0.074 \\
\hline USA and Canada & 3,650 & 54.5 & 18.5 & 40.2 & 1.4 & 71.4 & 37.6 & 0.7 & 2.7 & 11.6 & 239 & 0.061 \\
\hline China & 2,970 & 89.3 & 38.8 & 6.0 & 5.7 & 22.2 & 52.7 & 1.7 & 11.6 & 1.7 & 230 & 0.069 \\
\hline Japan & 2,810 & 92.3 & 65.0 & 11.0 & 0.4 & 31.4 & 29.9 & 0.2 & 7.9 & 3.9 & 242 & 0.078 \\
\hline Low-income countries (GNI 2-4) & 2,643 & 20.5 & 12.0 & 8.2 & 2.9 & 21.2 & 6.8 & 0.7 & 6.6 & 3.1 & 82 & 0.029 \\
\hline
\end{tabular}

Table 5. Median per capita daily intake of DHA (mg/day) and percent of daily total energy intake (\% energy) from food sources

\begin{tabular}{|c|c|c|c|c|c|c|c|c|c|c|c|}
\hline \multirow[t]{2}{*}{ Countries } & \multirow{2}{*}{$\begin{array}{l}\text { Energy } \\
\text { intake, } \\
\text { kcal/day }\end{array}$} & \multicolumn{9}{|c|}{ Per capita daily intake of DHA from food sources, $\mathrm{mg} /$ day } & \multirow{2}{*}{$\begin{array}{l}\text { DHA } \\
\text { as \% } \\
\text { energy }\end{array}$} \\
\hline & & eggs & $\begin{array}{l}\text { fish, } \\
\text { seafood }\end{array}$ & $\begin{array}{l}\text { bovine, } \\
\text { meat }\end{array}$ & $\begin{array}{l}\text { mutton } \\
\text { (goat), } \\
\text { meat }\end{array}$ & $\begin{array}{l}\text { poultry, } \\
\text { meat }\end{array}$ & $\begin{array}{l}\text { pig, } \\
\text { meat }\end{array}$ & $\begin{array}{l}\text { meat, } \\
\text { other }\end{array}$ & $\begin{array}{l}\text { offals, } \\
\text { edible }\end{array}$ & total & \\
\hline European Union & 3,420 & 6.0 & 170.1 & 2.1 & 0.3 & 5.2 & 8.9 & 0.4 & 5.2 & 198 & 0.052 \\
\hline Australia and New Zealand & 3,170 & 3.8 & 145.4 & 4.3 & 3.9 & 9.0 & 5.3 & 0.5 & 11.5 & 184 & 0.052 \\
\hline USA and Canada & 3,650 & 7.1 & 187.6 & 4.7 & 0.2 & 11.9 & 7.3 & 0.1 & 1.8 & 221 & 0.055 \\
\hline China & 2,970 & 10.0 & 267.3 & 0.6 & 0.8 & 3.4 & 9.4 & 0.3 & 6.3 & 298 & 0.090 \\
\hline Japan & 2,810 & 10.3 & 446.9 & 1.2 & 0.1 & 4.8 & 5.3 & 0.1 & 4.6 & 473 & 0.152 \\
\hline Low-income countries (GNI 2-4) & 2,643 & 2.3 & 84.5 & 0.9 & 0.4 & 3.2 & 1.2 & 0.1 & 3.7 & 96.3 & 0.033 \\
\hline
\end{tabular}

In developed countries, the median daily intake of ARA is between 210 and $250 \mathrm{mg} /$ day; however, the principal food sources vary with meat being the primary source of ARA in Europe, Australia, New Zealand, the United States and Canada, whereas in China and Japan, egg consumption is a major contributor to ARA intake. The median energy percentage of dietary ARA in the developed countries ranges from $0.055 \%$ in Europe to $0.078 \%$ in Japan (tables 3 and 4).

In 128 developing countries, the median ARA intake is $82 \mathrm{mg} /$ day and this relates to the estimated low meat $(62.6 \mathrm{~g} /$ day $)$ and egg ( $10.5 \mathrm{~g} /$ day) consumption. The median energy percentage of dietary ARA is $0.029 \%$, half of that reported for developed countries.

The dietary intake of fish and seafood was significantly lower in developing countries; however, there were several small island states that consumed exceptionally large quantities of seafood, especially Maldives. This dietary variation is reflected in the estimated DHA intake with the median intake in developing countries being $96 \mathrm{mg} /$ day, and this contrasts with the range of $184-473 \mathrm{mg} /$ day in the developed countries (tables 3,5).
The relationship between the median intake of DHA and ARA and the per capita GNI of the country are shown in table 6. There is a direct relationship between the estimated dietary ARA and DHA consumption and the per capita GNI of the country. The 28 countries in the lowest income category had a median ARA and DHA intake of 43 and $47 \mathrm{mg}$ /day, respectively, and this group represents a total population of nearly 740 million people (table 6). There was considerable regional variation with the lowest intake for both ARA and DHA being in Sub-Saharan Africa and Southern, Western and Central Asia (table 7).

In addition to economic factors, there was evidence of geographical and demographic relationships. There were 35 landlocked countries, and the median daily ARA and DHA intake were 88.2 and $47.4 \mathrm{mg} /$ day, respectively, and these intake values are in contrast to the intake values of 28 small island developing countries that had a median ARA and DHA daily intake of 156.5 and $204.7 \mathrm{mg} /$ day, respectively. With pregnant women and young children being a particularly vulnerable group to ARA and DHA deficiency, it is noted that across the 175 countries, there 
Table 6. Estimated median (range) per capita ARA and DHA intakes in 172 countries classified by the GNI and total population

\begin{tabular}{lclll}
\hline GNI & $\begin{array}{l}\text { Daily ARA intake, } \\
\text { mg/day }\end{array}$ & $\begin{array}{l}\text { Daily DHA intake, } \\
\text { mg/day }\end{array}$ & $\begin{array}{l}\text { Population, } \\
\text { millions }\end{array}$ & $\begin{array}{l}\text { Birth rate, } \\
\text { n/1,000 population }\end{array}$ \\
\hline High income $(\mathrm{n}=42)$ & $227(58-507)$ & $192(67-706)$ & 1,088 & $10.8(7.9-19.9)$ \\
Upper middle income $(\mathrm{n}=49)$ & $167(78-345)$ & $122(31-1,371)$ & 2,437 & $16.0(8.9-34.5)$ \\
Lower middle income $(\mathrm{n}=53)$ & $93(32-289)$ & $134(13-605)$ & 2,788 & $22.8(8.2-42.1)$ \\
Low income $(\mathrm{n}=28)$ & $43(18-192)$ & $47(6-437)$ & 740 & $35.1(20-45.6)$ \\
Total $(\mathrm{n}=172)$ & $147(18-507)$ & $134(6-1,371)$ & 7,053 & $18.0(7.9-45.6)$ \\
\hline
\end{tabular}

was a strong negative correlation between birth rate and ARA $(\mathrm{r}=-0.730 ; \mathrm{p}<0.001)$ and DHA $(\mathrm{r}=-0.277 ; \mathrm{p}<$ 0.001 ; table 6).

Detailed data for individual countries on the estimated intake of DHA and ARA and percentage daily energy intake are presented for developed (GNI 1) and developing (GNI 2-4) countries in tables 8 and 9. In the 47 developed countries, the ARA and DHA intake was the greatest in Iceland and lowest in Bosnia and Herzegovina. In the 128 developing countries, the highest intake for ARA and DHA was estimated to be in Maldives, which had the highest DHA and the second highest ARA of all the countries assessed. Rwanda and Ethiopia had the poorest estimated ARA and DHA consumption rates.

\section{Discussion}

This global study demonstrates that across 175 countries, of which 128 are recognised as developing nations, there is marked variation in per capita dietary intake of DHA and ARA. The countries that have been analysed represent the diverse geographic, economic and cultural factors that underpin global populations. The economic status of the country was a key factor with the data showing a direct relationship of dietary DHA and ARA to the per capita GNI of the country. The DHA and ARA intake of countries with low GNI are several times lower than that of high-income countries, and the 28 countries in the lowest GNI category represent a population of nearly 740 million people.

Current recommendations on DHA and ARA requirements are predominantly underpinned by research data generated in high-income countries and therefore, the relevance of these recommendations to populations living in low-income developing countries is questionable. The presented data provides evidence to support this view.

Global Dietary Intake of ARA and DHA
Table 7. Per capita median daily dietary intake of ARA and DHA in low-income regions (GNI 2-4)

\begin{tabular}{lrc}
\hline Region & $\begin{array}{l}\text { ARA intake, } \\
\text { mg/day }\end{array}$ & $\begin{array}{l}\text { DHA intake, } \\
\text { mg/day }\end{array}$ \\
\hline North Africa & $108.7(34-134)$ & $120.7(41-184)$ \\
Sub-Saharan Africa & $58.9(18-187)$ & $71.7(6-294)$ \\
East Asia & $155.6(69-345)$ & $302.5(35-605)$ \\
Southern Asia & $55.7(32-307)$ & $80.2(23-1,371)$ \\
Western Asia & $89.6(53-134)$ & $51.9(32-102)$ \\
Central Asia & $103.9(40-255)$ & $44.9(8-184)$ \\
Caribbean and Central & & \\
$\quad$ America & $151.7(41-284)$ & $134.2(28-561)$ \\
South America & $186.0(93-241)$ & $81.6(36-199)$ \\
\hline
\end{tabular}

Within any population, there are vulnerable groups and in relation to ARA and DHA, the optimal dietary intake of these fatty acids is particularly important in pregnant women, infants and young children. It is therefore notable that the DHA and ARA intake is the lowest in countries with the highest birth rates. It has previously been reported that maternal DHA status is reduced in multiparous women [35], and therefore, in the vulnerable low-income populations, the maternal and infant LCPUFA status will be susceptible to the dual adverse effects of multi-parity and poor maternal diet.

There are clear differences in dietary intakes of ARA and DHA food sources between high- and low-income countries and this is especially evident in the intake of seafood, eggs and poultry meat. Seafood is an important source of DHA in countries with access to a coastline, and in comparison to landlocked countries, significantly higher levels of DHA were noted in small developing islands even if they are low-income countries.

The strengths of the FAO FBS are that the data are readily available and up to date (through 2011), the data 
is easy to access and use, and there is an element of consistency as the data collection follows similar procedures. The estimates of intake are therefore comparable between countries and the data can be organized in a way that allows the user to identify countries with high and low consumption of commodities of interest. Internal consistency checks are inherent in the accounting technique of the FBS and this is supported by external consistency checks that are based on related supplementary information, such as the results of surveys conducted in various parts of the world [26].

Limitations include the fact that the data do not directly measure food consumption but instead reflect the food supply in a country and may not accurately capture non-food uses such as wastage. However, in this study, adjustments were specifically made for wastage that may occur at the retail and household levels [28]. It has been suggested that the FBS consumption data may be an overestimate compared to measurements of consumption that are recorded in either household or individual surveys [36-38]. However, the latter also have limitations as they are often dependent upon short-term dietary histories that may not reflect the annual dietary intake. For example, in the United States, $50 \%$ of fish available for consumption are in the categories of crustaceans, cephalopods and molluscs [27], which may present as a variety of processed food commodities that may not be captured in household surveys. However, if it is assumed that there is an element of overestimation within the presented data, it is reasonable to conclude that the reported low intake of ARA and DHA in the most vulnerable populations will be even more of concern.

Applying food composition data from a developed country such as Australia to the entire list of developing countries throughout all regions of the world is a limitation, as it may not necessarily reflect a national or even regionally representative level of ARA and DHA in the population's food supply. However, while there are alternative food composition databases that are publically available, they were considered unsuitable, as the number of foods was not sufficiently complete to provide a comprehensive estimate of the total ARA and DHA intake from known dietary sources. Therefore, in order to conduct a global assessment and to be able to compare the fatty acid intake between countries, the complete database from NUTTAB 2010 was considered a satisfactory selection based on the data available [30]. Moreover, the evidence that the data reflected anticipated effects of economic, demographic and geographic variables provided some credence to the validity of the data.
Table 8. Estimated daily ARA and DHA intakes (with \% energy) for countries in GNI 1 (in descending order of ARA intake)

\begin{tabular}{|c|c|c|c|c|}
\hline Country & $\begin{array}{l}\text { ARA } \\
\text { intake, } \\
\text { mg/day }\end{array}$ & $\begin{array}{l}\text { ARA \% } \\
\text { energy }\end{array}$ & $\begin{array}{l}\text { DHA } \\
\text { intake, } \\
\text { mg/day }\end{array}$ & $\begin{array}{l}\text { DHA \% } \\
\text { energy }\end{array}$ \\
\hline Iceland & 350.8 & 0.095 & 793.4 & 0.214 \\
\hline Portugal & 313.4 & 0.079 & 521.6 & 0.131 \\
\hline USA & 313.2 & 0.075 & 219.7 & 0.053 \\
\hline Spain & 307.2 & 0.085 & 396.8 & 0.109 \\
\hline Australia & 303.6 & 0.086 & 260.9 & 0.074 \\
\hline New Zealand & 299.7 & 0.086 & 259.5 & 0.074 \\
\hline France & 299.4 & 0.076 & 335.1 & 0.085 \\
\hline Israel & 285.5 & 0.073 & 216.7 & 0.055 \\
\hline Lithuania & 285.2 & 0.075 & 402.7 & 0.106 \\
\hline Bermuda & 282.8 & 0.102 & 163.7 & 0.058 \\
\hline Luxembourg & 280.7 & 0.069 & 278.3 & 0.068 \\
\hline Austria & 279.0 & 0.067 & 150.1 & 0.036 \\
\hline Belarus & 270.7 & 0.079 & 192.4 & 0.056 \\
\hline Denmark & 264.6 & 0.070 & 232.3 & 0.062 \\
\hline Italy & 261.6 & 0.064 & 246.8 & 0.061 \\
\hline Canada & 260.8 & 0.067 & 221.7 & 0.057 \\
\hline Japan & 260.6 & 0.084 & 483.0 & 0.155 \\
\hline Norway & 260.3 & 0.068 & 481.1 & 0.125 \\
\hline Malta & 258.3 & 0.065 & 290.8 & 0.073 \\
\hline Sweden & 258.0 & 0.074 & 290.7 & 0.084 \\
\hline Latvia & 256.4 & 0.076 & 268.3 & 0.080 \\
\hline Ireland & 252.8 & 0.065 & 228.1 & 0.058 \\
\hline Netherlands & 249.6 & 0.069 & 226.2 & 0.063 \\
\hline China & 249.4 & 0.076 & 306.7 & 0.093 \\
\hline Germany & 245.2 & 0.063 & 153.0 & 0.039 \\
\hline Czech Republic & 244.6 & 0.066 & 119.3 & 0.032 \\
\hline Belgium & 243.7 & 0.059 & 241.8 & 0.059 \\
\hline Russian Federation & 242.9 & 0.067 & 224.6 & 0.062 \\
\hline Finland & 239.7 & 0.067 & 323.8 & 0.091 \\
\hline United Kingdom & 238.8 & 0.063 & 192.7 & 0.050 \\
\hline Greece & 236.1 & 0.057 & 201.3 & 0.049 \\
\hline Slovenia & 235.5 & 0.066 & 127.2 & 0.036 \\
\hline Cyprus & 228.2 & 0.064 & 223.6 & 0.063 \\
\hline Switzerland & 228.0 & 0.060 & 178.6 & 0.047 \\
\hline Hungary & 218.9 & 0.057 & 75.2 & 0.020 \\
\hline Poland & 213.7 & 0.057 & 131.2 & 0.035 \\
\hline Estonia & 211.4 & 0.060 & 159.8 & 0.046 \\
\hline Ukraine & 207.8 & 0.058 & 149.0 & 0.042 \\
\hline Montenegro & 201.6 & 0.067 & 114.7 & 0.038 \\
\hline Romania & 201.2 & 0.052 & 82.6 & 0.021 \\
\hline Croatia & 200.2 & 0.060 & 186.8 & 0.056 \\
\hline Slovakia & 191.7 & 0.060 & 93.0 & 0.029 \\
\hline Bulgaria & 174.3 & 0.057 & 83.3 & 0.027 \\
\hline Serbia & 156.4 & 0.052 & 77.2 & 0.026 \\
\hline Republic of Moldova & 146.9 & 0.045 & 139.0 & 0.043 \\
\hline Albania & 145.9 & 0.042 & 70.7 & 0.021 \\
\hline Bosnia and Herzegovia & 101.0 & 0.030 & 64.6 & 0.019 \\
\hline
\end{tabular}


Table 9. Estimated daily ARA and DHA intakes (with \% energy) for countries in GNI 2-4 (in descending order of ARA intake)

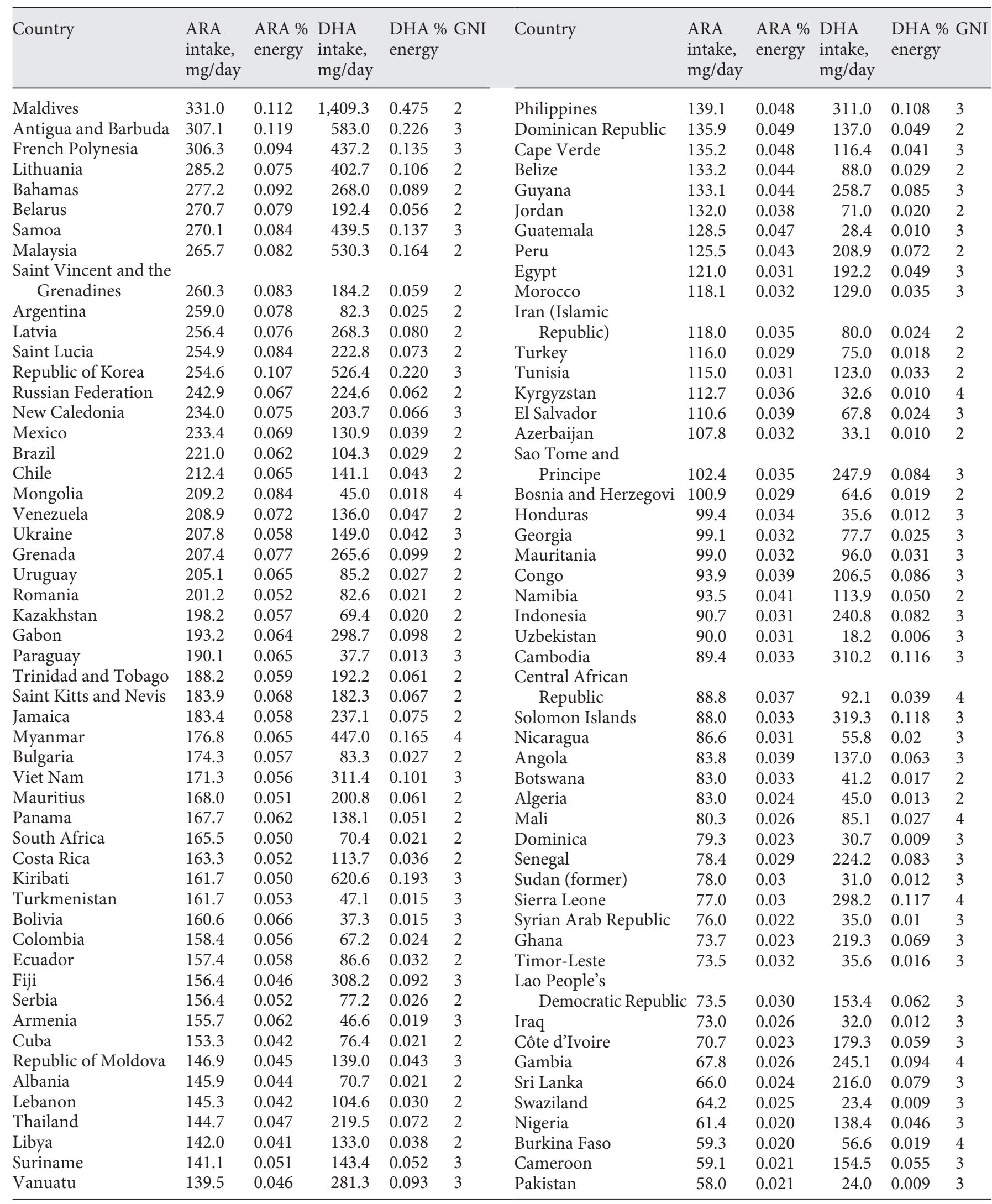


Table 9. (continued)

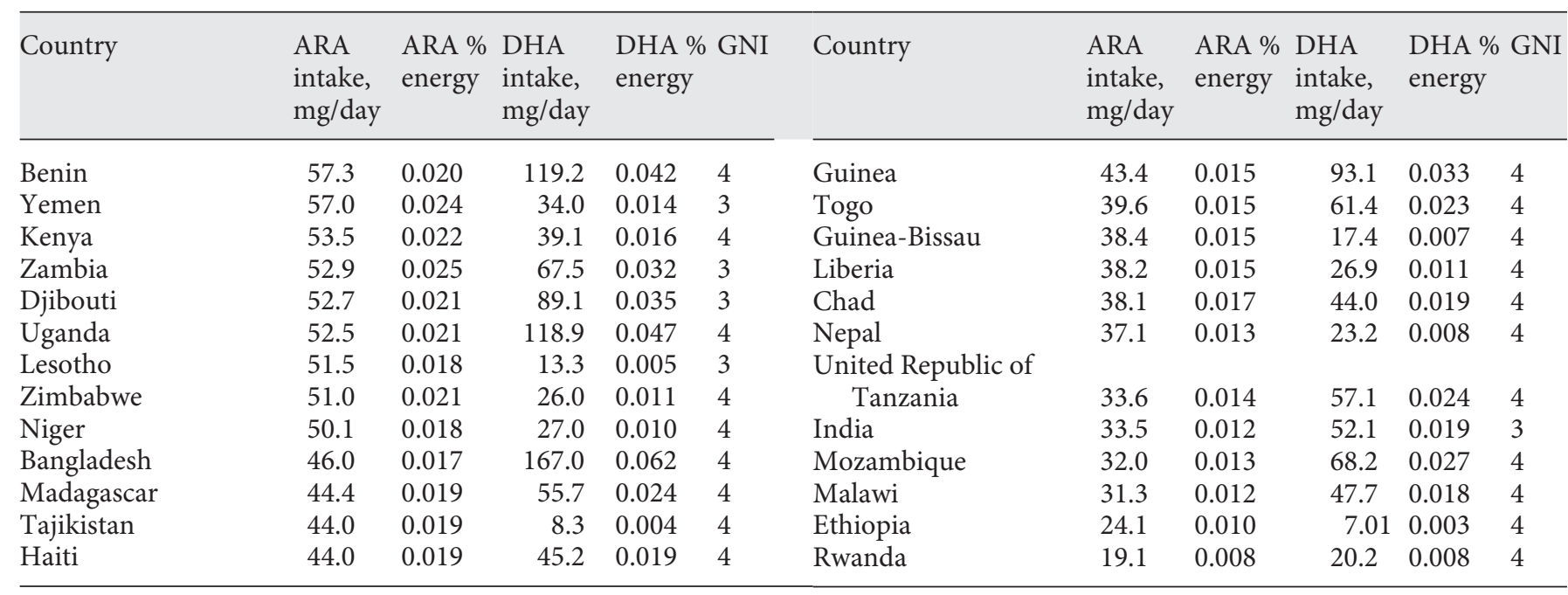

A similar methodology has been used in previous studies including that of Hibbeln et al. [39], who utilised data from FAOSTAT to measure n-3 LCPUFA dietary intake in 38 predominantly developed countries and related their data to age-adjusted mortality due to cardiovascular disease, coronary heart disease and stroke. They determined that the greatest protection was provided by a total $n-3$ LCPUFA dietary intake of $750 \mathrm{mg} /$ day, which most closely correlated with the dietary intake of the Japanese population. A detailed food survey by Kuriki et al. [40] reported that Japanese dieticians had a DHA dietary intake of 510-590 mg/day and an ARA intake of $150 \mathrm{mg} /$ day. This data is consistent with the findings from the current study, with the estimated daily dietary intake for Japan being 473 $\mathrm{mg}$ /day for DHA and $242 \mathrm{mg}$ /day for ARA.

Michaelsen et al. [41] utilised FAOSTAT data to estimate the availability of fat and fatty acids in 13 low-income and middle-income countries and reported that the total the recommended intake range for infants and young chilGDP. in both developed and developing countries and demonstrates that there are many regions and populations that have an intake of DHA and ARA that does not reflect cur- rent international recommendations. Within individual populations, vulnerable groups including pregnant women, infants and young children may be particularly at risk of the global diversity in LCPUFA intake and the potential public health consequences need to be urgently considered.

\section{Disclosure Statement}

Professor Forsyth undertakes consultancy work for DSM, and Mrs. Gautier and Dr. Salem are employees of DSM. DSM is a major producer of nutritional ingredients including arachidonic acid and docosahexaenoic acid. n-3 fatty acid supply is below or close to the lower end of dren, and below the minimum recommended level for pregnant and lactating women in the 9 countries with the lowest gross domestic product (GDP). They also demonstrated that the availability of food sources for ARA was significantly reduced in the countries with the lowest

In conclusion, this study provides a comprehensive global perspective on the dietary intake of DHA and ARA

References 
6 Crawford MA, Wang Y, Forsyth S, Brenna JT: The European food safety authority recommendation for polyunsaturated fatty acid composition of infant formula overrules breast milk, puts infants at risk, and should be revised. Prostaglandins Leukot Essent Fatty Acids 2015;102-103:1-3.

7 Mathias RA, Pani V, Chilton FH: Genetic variants in the FADS gene: implications for dietary recommendations for fatty acid intake. Curr Nutr Rep 2014;3:139-148.

8 Salem N Jr, Wegher B, Mena P, Uauy R: Arachidonic and docosahexaenoic acids are biosynthesized from their 18-carbon precursors in human infants. Proc Natl Acad Sci U S A 1996;93:49-54.

-9 Pawlosky RJ, Lin YH, Llanos A, Mena P, Uauy R, Salem N Jr: Compartmental analyses of plasma $13 \mathrm{C}$ - and $2 \mathrm{H}$-labeled $\mathrm{n}-6$ fatty acids arising from oral administrations of $13 \mathrm{C}-\mathrm{U}$ 18:2n-6 and 2H5-20:3n-6 in newborn infants. Pediatr Res 2006;60:327-333.

-10 Brenna JT, Salem N Jr, Sinclair AJ, Cunnane SC; International Society for the Study of Fatty Acids and Lipids, ISSFAL: Alpha-linolenic acid supplementation and conversion to $\mathrm{n}-3$ long-chain polyunsaturated fatty acids in humans. Prostaglandins Leukot Essent Fatty Acids 2009;80:85-91.

11 DeMar JC Jr, Ma K, Chang L, Bell JM, Rapoport SI: Alpha-linolenic acid does not contribute appreciably to docosahexaenoic acid within brain phospholipids of adult rats fed a diet enriched in docosahexaenoic acid. J Neurochem 2005;94:1063-1076.

12 DeMar JC Jr, Lee HJ, Ma K, Chang L, Bell JM, Rapoport SI, et al: Brain elongation of linoleic acid is a negligible source of the arachidonate in brain phospholipids of adult rats. Biochim Biophys Acta 2006;1761:1050-1059.

$\checkmark 13$ Hussein N, Ah-Sing E, Wilkinson P, Leach C, Griffin BA, Millward DJ: Long-chain conversion of [13C]linoleic acid and alpha-linolenic acid in response to marked changes in their dietary intake in men. J Lipid Res 2005;46: 269-280.

14 Koletzko B, Lattka E, Zeilinger S, et al: Genetic variants of the fatty acid desaturase gene cluster predict amounts of red blood cell docosahexaenoic and other polyunsaturated fatty acids in pregnant women: findings from the avon longitudinal study of parents and children. Am J Clin Nutr 2011;93:211-219.

15 Harsløf LB, Larsen LH, Ritz C, Hellgren LI, Michaelsen KF, Vogel U, et al: FADS genotype and diet are important determinants of DHA status: a cross-sectional study in Danish infants. Am J Clin Nutr 2013;97:1403-1410.

-16 Sergeant S, Hugenschmidt CE, Rudock ME: Differences in arachidonic acid levels and fatty acid desaturase (FADS) gene variants in African Americans and European Americans with diabetes or the metabolic syndrome. Br J Nutr 2012;107:547-555.
17 DeMar JC Jr, Di Martino C, Baca AW, Lefkowitz W, Salem N Jr: Effect of dietary docosahexaenoic acid on the net accumulation of docosahexaenoic acid biosynthesized from alpha-linolenic acid in rat organs. J Lipid Res 2008;49:1963-1980.

18 WHO: Diet, Nutrition, and the Prevention of Chronic Diseases. Geneva, Switzerland, World Health Organisation, 2003.

19 European Food Safety Authority: Scientific opinion on dietary reference values for fats, including saturated fatty acids, polyunsaturated fatty acids, monounsaturated fatty acids, trans fatty acids, and cholesterol. EFSA J 2010;8:1461.

20 International Society for the Study of Fatty Acids and Lipids: Report of the Sub囚Committee on Recommendations for Intake of Polyunsaturated Fatty Acids in Healthy Adults. 2004. http://www.issfal.org/news-links/resources/ publications/PUFAIntakeReccomdFinal Report.pdf.

21 Food and Agriculture Organization of the United Nations: Fats and Fatty Acids in $\mathrm{Hu}-$ man Nutrition: Report of an Expert Consultation. Geneva, FAO Food and Nutrition, November 10-14, 2008. http://www.fao.org/ docrep/013/i1953e/i1953e00.pdf.

22 Calder PC: Dietary arachidonic acid: harmful, harmless or helpful? Br J Nutr 2007;98:451453.

23 Koletzko B, Boey CC, Campoy C, Carlson SE, Chang N, Guillermo-Tuazon MA, et al: Current information and Asian perspectives on long-chain polyunsaturated fatty acids in pregnancy, lactation, and infancy: systematic review and practice recommendations from an early nutrition academy workshop. Ann Nutr Metab 2014;65:49-80.

24 Belgian Health Council: Voedingsaanbevelingen Voor België. Herziene Versie. Nutritional Recommendations for Belgium. 2000. https://portal.health.fgov.be/pls/portal/.

25 Sioen I, Huybrechts I, Verbeke W, Camp JV, De Henauw S: n-6 and n-3 PUFA intakes of pre-school children in Flanders, Belgium. $\mathrm{Br}$ J Nutr 2007;98:819-825.

26 Food and Agriculture Organization of the United Nations: Food Balance Sheets: A Handbook. Rome, Food and Agriculture Organization of the United Nations, 2001. http://www. fao.org/docrep/003/x9892e/x9892e00.htm.

27 Food and Agriculture Organization of the United Nations (FAO): FAOSTAT Data, 2015. http://faostat3.fao.org/browse/FB/*/E.

28 FAO: Global Food Losses and Food Waste Extent, Causes and Prevention. Rome, 2011.

29 US Department of Agriculture, Agricultural Research Service: USDA National Nutrient Database for Standard Reference, Release 27. Nutrient Data Laboratory Home Page, 2014. http://www.ars.usda.gov/nutrientdata.
30 Food Standards Australia New Zealand (FSANZ): NUTTAB 2010, 2011. http://www. foodstandards.gov.au/science/monitoring nutrients/nutrientables/Pages/default.aspx (accessed January 2016).

31 Development Policy and Analysis Division of the Department of Economic and Social Affairs of the United Nations Secretariat: Data Sources, Country Classifications and Aggregation Methodology. www.un.org/en/development/ desa/policy/wesp/wesp_current/2014wesp_ country_classification.pdf.

32 Central Intelligence Agency: The World Fact Book. Coastline. https://www.cia.gov/library/ publications/the-world-factbook/fields/2060. html.

33 United Nations Department of Economic and Social Affairs: Population Division: Population Estimates and Projections Section, June 13, 2013. http://www.un.org/en/development/ desa/population/ (retrieved June 18, 2013).

34 Central Intelligence Agency: The World Fact Book. Birth Rate. https://www.cia.gov/library/ publications/the-world-factbook/fields/2054. html.

$35 \mathrm{Al} \mathrm{MD}$, van Houwelingen AC, Hornstra G: Long-chain polyunsaturated fatty acids, pregnancy, and pregnancy outcome. Am J Clin Nutr 2000;71(1 suppl):285S-291S

36 US Environmental Protection Agency (EPA): Estimated Fish Consumption Rates for the U.S. Population and Selected Subpopulations (NHANES 2003-2010). Final Report, 2014.

37 Food and Agriculture Organisation of the United Nations: FAO Statistics Division: Estimating Food Consumption Patterns by Reconciling Food Balance Sheets and Household Budget Surveys. Rome, Food and Agriculture Organisation of the United Nations, 2014.

38 Del Gobbo LC, Khatibzadeh S, Imamura F, Micha R, Shi P, Smith M, et al: Assessing global dietary habits: a comparison of national estimates from the FAO and the global dietary database. Am J Clin Nutr 2015;101:10381046.

39 Hibbeln JR, Nieminen LRG, Blasbalg TL: Healthy intakes of $n 3$ and $n 6$ fatty acids: estimations considering worldwide diversity. Am J Clin Nutr 2006;83(suppl):1483S-1493S.

40 Kuriki K, Nagaya T, Imaeda N, TokudomeY, Fujiwara N, Sato J, et al: Discrepancies in dietary intakes and plasma concentrations of fatty acids according to age among Japanese female dietitians. Eur J Clin Nutr 2002;56: 524-531.

41 Michaelsen KF, Dewey KG, Perez-Exposito $A B$, et al.: Food sources and intake of $n-6$ and $\mathrm{n}-3$ fatty acids in low-income countries with emphasis on infants, young children (6-24 months), and pregnant and lactating women. Matern Child Nutr 2011;7(suppl 2):124140 